\title{
Income Concentration, Market Size and Informal Sector in Africa
}

\author{
${ }^{1}$ Tchakounté Njoda Mathurin, ${ }^{2}$ Hamit Halou Chalout \\ ${ }^{1}$ FSEG, University of Ngaoundéré, Ngaoundéré, Cameroon \\ ${ }^{2}$ Commercial Technical Education High School of Moundou, Moundou, Chad
}

\begin{abstract}
In this study, we analyze the link between income concentration and the size of the informal sector. We construct a simple model where income concentration determines demand and firms decide whether to operate in the formal or the informal economy is outlined. The government collects taxes and returns them to society either as a productive public good for its use by formal firms or as transfers to the poor. It is further postulated that income distribution affects the response of the informal sector to different fiscal policies, either demand or supply-orientated. In this case, redistribution towards the middle class decreases the size of the informal sector and increases the capacity of fiscal instruments to reduce informality. Data concerns 38 Africans' countries in which the characteristic of income distribution is similar across countries. Using this comparable macro-level panel data between 1991 and 2013, we find strong evidence that high-income concentration leads to a large informal sector. Furthermore, an economic policy, including the effective application of the tax and regulatory procedures, should help to keep down the size of the informal economy.
\end{abstract}

Keywords: Income concentration, Market size, Labor market, Informal sector

\section{Introduction}

One sector in Africa which has a great potential for necessary domestic income mobilization and to reduce huge budget deficits is the informal economy/sector ${ }^{1}$. While the informal economy has shown a marginal decline in most developed countries in the early 2010s, it has been growing in the rest of the world, particular in Africa, countries that have the most significant informal sectors, ranging around, and even above, $50 \%$ of official GDP (Charmes, 2000; Bajada and Schneider, 2005; Schneider, 2014). A large number of the continent's active labor force is employed in the informal sector and accordingly generates a significant amount of revenue that is subject to come tax. If the sector is expected to expand exponentially in the near future, perhaps it should serve as a "goldmine" for higher income mobilization².

Among the main challenges confronting the governments of the third world in their forward march to the socio-economic development is how to manage the phenomenon of the fledging informal economy and maximization of income tax from that sector (Bargain and Kwenda, 2011). Levenson and Maloney (1998) provide an interpretation of the emergence of an informal sector, in particular to the size choice of informal. They state that small firms do not scale down to avoid paying taxes, but their limited investment needs and the narrow nature of their operations make stable property rights unimportant and the gains from civic participation flimsy.

${ }^{1} \mathrm{~F}$. Schneider (2011) defines the informal sector as market-based economic activities that are concealed from public authorities to avoid paying taxes and social security contributions and, more generally, elude regulation.

2 Given their high potential for job creation and income generation in Africa, the informal sector is gaining the attention of policymakers. Therefore, data on various characteristics and operations of these enterprises, the output generated, employment provided, and constraints faced and their relationship with the formal sector are needed. 
However, in Africa, there remain a large number of informal sector enterprises outside the income tax net. Naturally, since the benefits from participating in societal institutions grow larger as firms do, voluntary compliance and they will be charged (i.e., taxed) for participation arise. In other words, firms evolve from informality to formality as they grow to their long-run equilibrium size. During the last decades, self-employment and entrepreneurship emerged as significant income-earning opportunities in the face of rapidly declining wages (Van der Berg et al., 2005). Roberts (1994) argues that, given the scarcity of jobs in formal firms during the recession, the need to supplement family income spurred the creation of small businesses in sectors and activities characterized by ease of entry.

More recently, labor's share has also been seen as offering insights into the shape of the aggregate production function. This has made labor's share a parameter of interest for macroeconomics, grow th economics, and international economics, among other fields. Recent studies support the long-standing observation that labor's share of national income ${ }^{3}$ is relatively constant over time and a cross countries. Measurement of labor income, however, can be difficult in economies where many people are self-employed or work in family enterprises. Dereck and Lugo (2011) argued that developing countries typically have far higher levels of self-employment than do developed countries; as a result, cross-country comparisons of the employee compensation share (or wage share) will tend to yield significant differences between developed and developing countries. Gollin (2002) showed that, after adjusting labor's share to account for differences in self-employment rates, no systematic patterns remained in the cross-country data between a country's income and its imputed labor share. Gollin reported labor shares in most nations, adjusted for self-employment, between 0.6 and 0.8 . Similar results were obtained by Bernanke and Gürkaynak (2002), who used a different approach to regulate for a fraction of output produced by unincorporated enterprises.

Notably, in developing countries, the self-employed and the people working in family enterprises account for a huge portion of the workforce and informality. Self-employment represents not only emerging entrepreneurship and business start-up but also marginal employment and disguised unemployment (Gray, Howard, and Howard, 2006). As a result, in Africa, labor income is badly understated by the employees' compensation measure, which also risks changing significantly only as a consequence of a possible trend a way from informal employment. Income distribution - called income concentration when the distribution of income is concentrated among some members of the population - has been the central topic in economics since the days of Gregory King and William Petty. For the classical economists, as Kravis (1962) noted, the distribution of income among the suppliers of labor, land, and capital was the most efficient indicator of the relative welfare of different social groups. Thus wages, profits, and rents represented the income of workers, entrepreneurs, and proprietors respectively. Such a direct identification of social groups with particular types of income cannot, however, be made so readily for the recent past. The remuneration of production factors is today central to the various kinds of studies.

The largest share of national income is the labor's share, and within labor income, wages are the most essential components, though labor income includes other kinds of labor remunerations in addition to wages. In order to appropriately measure the labor income, it is necessary to establish which proportion of the income of proprietors, unpaid family workers, the selfemployed and retired workers represent returns to labor. It should be noted that selfemployment, rather than wage employment, dominate in developing countries, as it did in most historical cases. Also, the empirical analysis of the functional distribution of income and in particular of labor's share is handicapped by the fact that data has not been determined by the requirements of economic analysis but rather by the legal and institutional arrangements of the society. Thus, indirect methods have to be used to quantify these shares.

${ }^{3}$ Economists have long studied labor's share of national income as a crude indicator of income concentration. 
Differences in labor's share across countries reflect more disparities in the structure and scale of firms than in the sectoral composition of output. Thus in developing countries, rates of selfemployment are higher than in developed countries as the share of larger firms is smaller. Consequently, today's differences in employee shares across countries are explained by the relative sizes of the earnings obtained by the self-employed, unpaid family workers, and business owners.

The structure of the market, especially, the demand that firms face, is likely to be a determinant of the size of the informal sectoras important as the governmental burden imposed on businessmaking. A firm deciding the sector in which to operate would compare the benefits from producing with scale economies and paying taxes against the profits of producing under a less efficient technology. If a demand expansion occurs, ceteris paribus, the benefits of formality become evident as it eases meeting the higher demand and generating the corresponding profits, leading to a further reduction in the costs of formality.

In this paper, we argue that income distribution plays a role in the determination of the size of the informal sector as it shapes the way the market, mostly aggregate demand, behaves. In this fashion, income distribution influences the environment in which a firm decides its size and its formality status. Furthermore, as a by-product of the analysis, we postulate that income distribution affects the response of the informal sector to different fiscal policies, either demand or supply-orientated. The literature is basically silent on these matters whose importance lies in the fact that they may add a new perspective in evaluating the effects of redistributive policies, especially in developing countries (Grimm, Krüger and Lay, 2011). Indeed, there are just a few previous works explored the relationship between income distribution and the size of the informal economy, all of them based on different theoretical motivations from the one stressed here (Rauch, 1993; Chong and Gradstein 2007).

To sum up, even though our estimates should be interpreted with care, they do suggest an overall trend in size and latest development of informal sectors around African countries. In this paper, we address some of these issues and model size of informal sector according to the formal one in concert with demand and income distribution in the economy. After the introduction, the next section presents the theoretical model including equilibrium analysis and comparative statics. Section 2 reports hypothesis, measurements of variables and data employed. Section 4 gives the empirical approach and data analysis. Section 5 summarizes and concludes.

\section{Theoretical Model}

\subsection{Structure of Model}

The model is based on a continuum of productive sectors $z \in[0, \infty[$. Each one consists of just one competitive firm which produces a homogenous good using labor, which is also homogenous, as the unique input. The input requirement for any sector to produce a unit of output is $a>1$ and labor is paid a wage $w$.

In each sector, the firm can be either of two types: informal or formal. An informal firm has profits $\pi_{z}^{I}=\left(p_{z}-\alpha w\right) Q_{z}$, where $p_{z}$ and $Q_{z}$ are, respectively, the price and quantity produced of good $z$. Competition implies that in equilibrium $p_{z}=p=\alpha w$ and $\pi_{z}^{I}=0$. Alternatively, a firm can belong to the formal sector. If so, it must pay a fixed entry fee $T$ to the government, which can be interpreted as a tax rate, and it receives a benefit in exchange: its unit labor requirement reduces to $a(1-\rho)<a$, where $\rho \in(0,1)$ is a productivity-enhancing factor that arises from the access to productive public services. Hence, the profits of a formal firm are $\pi_{z}^{F}=$ $\left[p_{z}-\alpha(1-\rho) w\right] Q_{z}-\tau$. 


\section{Income Concentration, Market Size and Informal Sector in Africa \\ Tchakounté Njoda Mathurin, Hamit Halou Chalout}

Since goods are homogenous, a formal firm may compete with informal. Charging a price higher than $p$ implies zero sales for the former while taking a lower price rule out informal firms. To maximize profits, the price charged will be infinitesimally below $p$, so, in equilibrium, a formal firm charges $w$ hat it would be charged by an informal $p_{z}=p=\alpha w$. Thus, $p=\alpha w$ for every sector, regardless of the size of the informal sector and of the type of the firm.

Consider a sector $q(q \in z)$ in which the firm is indifferent between being formal or informal, i.e. $\pi_{q}^{F}=\pi_{q}^{I}=0$. If $N_{q}$ denotes the demand for good $q$, the zero profits condition implies that

$$
N_{q}=\frac{\tau}{\alpha w \rho}
$$

For given $T, \rho$ and $w$, the firm's decision to be in the formal sector depend on the demand it faces. From (1) it can be seen that if a firm $z$ has a demand $Q_{z}<N_{q}$ then it will be informal as $\pi_{z}^{F}<0=\pi_{\mathrm{z}}^{\mathrm{I}}$; contrarily, if $Q_{z}>N_{q}$, the firm benefits from formality since $\pi_{z}^{F}>0=\pi_{\mathrm{z}}^{\mathrm{I}}$. Thus, $N_{q}$ is the break-even demand level (or size) of a formal firm. As such, it is easy to see that a rise in $N_{q}$ would make it harder for firms to enter the formal sector, as the minimum demand requirement to make formality worthy increases.

There is also a continuum of length one of the households, each inhabited by one individual, which are identical in all aspects except in their income from rents. As ownership of the productive firms is assumed to be random, so is income. A typical household consumes only a unit of each good $z$ and has a utility $U=\int_{0}^{\infty} \beta_{z} x_{z} \mathrm{~d} z=1$ where $x_{z}=1$ if good $z$ is consumed and $x_{z}=0$ if not. We assume that $\beta_{z}$ is decreasing in $z$. This implies that the individual consumes good $z$ as long as he has consumed all the other goods with indices less than $z$. In other words, goods are ordered in terms of priority.

If the household's income is $y$, then it's budget constraint is $\int_{0}^{\infty} p_{z} x_{z} \mathrm{~d} z \leq y$, and the solution of the utility maximization problem is straightforward: this household chooses $x_{z}=1$ for $z \in\left[0, z^{*}\right]$ and $x_{z}=0 x_{z}=0$ for $z \in\left[z^{*}, \infty\left[\right.\right.$ where $z^{*}$ is given by $y=\int_{0}^{z *} p_{z} \mathrm{~d} z=\alpha w z *$

Note that since there is a direct mapping from $U$ to $z^{*}$, the numbers of goods consumed $z^{*}$ and income $y$ are themselves indirect utility measures. Thus, an increase in utility is achieved only by augmenting the number (variety) of goods the household purchases.

Preferences are non-homothetic ${ }^{4}$ and lead to demand complementarity (in the sense of HicksAllen) from lower-indexed goods to higher-indexed goods, but not the other way around. Thus, an increase in income or a reduction in $p$ increases the demand for higher-indexed goods without affecting the demand for lower-indexed goods. To be more precise, the marginal propensity to consume a good with a higher index than $z^{*}$ is one, whereas it is zero for any good $z<z^{*}$.

Income is composite by wages and rents. Every household supplies inelastically a unit of labor and receives a wage $w$ in exchange. It also owns a share $\theta \in(0 ;[\theta p, \infty[)$ of all the profits in the economy $n$ (defined below), so its income is $y=w+\theta n$.

The shares are given randomly. Let $R(\theta)$ be the number of people whose share is less than or equal to $\theta$. The number of shareholders is $N_{p}=1-R\left(\theta_{p}\right)$, so there are $R\left(\theta_{p}\right)$ people with income $y=w$ who cannot purchase any good traded in the market since $p=a w>w$. We shall refer to the subset $R\left(\theta_{p}\right)$ as the "poor."

\footnotetext{
${ }^{4}$ i.e., income changes the marginal utility over goods.
} 


\section{Income Concentration, Market Size and Informal Sector in Africa Tchakounté Njoda Mathurin, Hamit Halou Chalout}

Given the non-homotheticity of preferences, income distribution determines aggregate demand. Households with income greater than $y_{z}=w+\theta_{z} \pi$ purchase one unit of good $z$. Since each household buys only one unit of each good he can afford, the aggregate demand for good $z$ is $N_{z}=1-R\left(\theta_{z}\right)$.

Almost all households consume goods at the lower end of the spectrum. As their income levels go up, the households expand their range of consumption by adding higher-indexed goods to their basket. Hence, rich households consume the same goods as the poor plus some more, implying that $N_{z}$ is decreasing in $z$. Therefore, following the firms' decision surrounding equation (1), firms in sectors $z \in[0, q]$ will be formal whereas firms in $z \in[q, \infty$ [ prefer informality.

The role of the government in the model is to collect taxes and return them to society in the form of the productivity factor $\rho$. Let $\mathrm{g}$ be the fiscal expenditure designated to the provision of the public service. As tax receipts come from formal firms only, the fiscal balance identity is $g=$ $\int_{0}^{\mathrm{q}} \tau \mathrm{d} z=\tau q$. The public service is produced with the following technology: $\rho=\rho(g)$ where $0<\lim _{g \rightarrow 0} \rho<\lim _{g \rightarrow \infty} \rho<1$. The elasticity of $\rho$ concerning the public expenditure $\varepsilon_{g}=(\mathrm{d} \rho / \mathrm{d} g)(g / \rho) \geq 0$ is assumed to be small.

\subsection{Labor Market Equilibrium}

The expenditure of a household that consumes goods in the interval $[0, q]$ is $p q=a w q$ whereas the income that allows it to purchase these goods is $y_{q}=w+\theta_{q} \pi$, hence

$$
\alpha w q=w+\theta_{q} \pi
$$

Now, equilibrium can be found upon aggregation of the individual expenditures.

From the above discussion, note that consumers with $\theta \in\left[\theta_{p}, \theta_{q}\right]$ spend all their income on goods sold in the formal sector. On the other hand, consumers with $\theta \in\left[\theta_{q}, \infty\right.$ [ only spend the share $\theta_{q}$ of their rents in such goods. Hence, the total sales of the formal sector equal the aggregate spending in goods $z \in[0, q]$,

$$
S^{F}=\alpha w Q^{F}=\int_{\theta_{p}}^{\theta_{q}} \min \left\{w+\theta \pi, w+\theta_{q} \pi\right\} \mathrm{dR}(\theta)=w N_{p}+\left(\Theta_{q}+\theta_{q} N_{q}\right)
$$

where $Q^{F}$ is the aggregate production in the formal sector and $\Theta_{q}=\int_{\theta_{p}}^{\theta_{q}} \theta d R(\theta)$ is the share of profits in the hands of the people belonging to the "middle class."

It is useful to compare (3) with the overall sales (in both sectors): $\quad S=\alpha w\left(Q^{F}+Q^{I}\right)=\int_{\theta_{p}}^{\infty}(w+$ $\theta \pi) d R(\theta)=w N_{p}+\pi \Theta$, where $\Theta_{q}=\int_{\theta_{q}}^{\infty} \theta d R(\theta)$ and $Q^{I}$ is the supply of goods from the informal sector.

It can be seen that while total sales are determined by the income of all shareholders, the sales of the formal sector depend on the income of the middle class and a fraction of the income of the "upper class" (the subset with $\theta>\theta_{q}$ ). This fact follows from the demand structure of the model: as the lower-indexed goods are at the top of the preference ranking, aggregate demand will be high and hence the benefits from formality are sizeable in those sectors. Thus, a wealthier individual can afford to buy higher-indexed goods so that she contributes to the sales of low demand firms.

Aggregate profits are $\pi=\alpha w \rho=Q^{F}-\tau q$. Rearranging using (1), (2) and (3) leads to 


$$
\pi=\left(\frac{1}{1-\rho \Theta_{q}}\right) \rho w\left(N_{p}+N_{q}\right)
$$

Remarkably, the sales to the upperclass allow formal firms to face the entry costs $T$. This is captured in the last term of equation (3), $\theta_{q} \pi N_{q}$. It is easy to show that $\rho \theta_{q} \pi N_{q}=\tau q$. The remaining sales, those aimed at the middle class, give formal firms profits that are eventually redistributed among households. When an individual enters the middle class and purchases a good in the formal sector, profits increase by $\rho w\left(N_{p}+N_{q}\right)$ where $\rho$ is the profit rate of formal firms. Then, a fraction of $\Theta_{q}$ of the generated profits is redistributed to the middle class and comes back as demand for further formal goods, leading to an extra increase in profits of $\rho \Theta_{q}$. As this process continues indeterminately, a multiplier effect arises with $\left(1-\rho \Theta_{q}\right)^{-1}>1$ being the multiplier.

The labor market equilibrium condition is $L^{F}+L^{I}=1$ or $\alpha(1-\rho) Q^{F}+\alpha Q^{I}=1$. Provided that labor supply is fixed, that each household supplies inelastically a unit of labor and that the same labor input is demanded by the formal and informal sectors, there exists a positive wage rate that clears the labor market. From now on, the wage is treated as the numeraire, $w=1$.

It is worth noting that as $L^{I}+\alpha Q^{I}$, an increase in $L^{I}$ is associated with a proportional increase in the sales of the informal sector and vice versa. This tight relationship does not hold necessarily in the formal sector, $L^{F}=\alpha(1-\rho) Q^{F}$, where an increase in $L^{F}$ may be associated with a higher input requirement, i.e., a smaller $\rho$, even when sales are kept unchanged. Moreover, as the labor supply is constant, a change in $L^{F}$ is compensated with a similar change (with the opposite sign) in $L^{I}$. Consequently, if the goods market in the formal sector is in equilibrium, so are the labor market (in both sectors) and the goods market in the informal sector. Thus, equations (1) and (4) alone define the goods and labor market equilibria.

Apart from the goods and labor markets described, there is a third market that has not been modeled explicitly, which entails the transactions carried "outside the market" by the $\mathrm{R}\left(\theta_{p}\right)$ people defined as poor, with an aggregate income of $w \mathrm{R}\left(\theta_{p}\right)=\mathrm{R}\left(\theta_{\mathrm{p}}\right)$. This market has many interpretations, for example, that of a subsistence good that is a substitute of the good traded in the model economy (though the latter is strictly preferred). By Walras's law, equilibrium is reached if both (1) and (4) are solved. Notice that we are implicitly assuming that the profits in this market are zero and, hence, do not contribute to aggregate wealth.

Given $R(\theta)$, two opposite forces lead to equilibrium following the setting of the tax rate $T$. At the firm level, a tax increase has a negative effect on the profits on the marginal firm $q$ as the savings from contracting less labor are more than offset by the higher tax burden ${ }^{5}$. This increases informality and drops tax revenues and profits. At the a gregate level, on the contrary, for a given tax base $\mathrm{q}$, a tax increase raises the multiplier and in turn aggregate profits. It follows a rise in income, demand, formality and tax revenues. The same reasoning applies for a tax reduction.

Both of these effects interact, and the consequence is the presence of multiple equilibria, as in Johnson, Kaufmann, and Shleifer (1997), i.e., the coexistence of "bad" high informality - low tax revenues - low demand equilibria with "good" low informality - high tax revenues - high demand equilibria. Which equilibrium the economy ends in will depend on initial conditions and, crucially, on income distribution (i.e., the degree of inequality). These facts suggest that the "optimal" level of $T$ (and hence $\rho$ ) is an interior solution, as in Barro and Sala-i-Martin (1992) and Loayza (1996).

\footnotetext{
${ }^{5}$ This follows directly from the definition of $N_{q}$ in (1).
} 


\subsection{Income Share and Redistribution}

Equations (1) and (4) (with $w=1$ ) represent two curves in the $\left(N_{q}, \pi\right)$ plane, $N_{q}=\frac{\tau}{\alpha w \rho}$ (curve (1) or $M$-curve) and $\pi=\left(\frac{1}{1-\rho \Theta_{\mathrm{q}}}\right) \rho w\left(\mathrm{~N}_{\mathrm{p}}+\mathrm{N}_{\mathrm{q}}\right.$ ) (curve (2) or $F$-curve), and constitute the toolbox for the comparative statics analysis (figure 1 and 2 ). The $F$-curve relates profit generation with the presence of informal firms. This scheme has a negative slope since a higher value of $N_{q}$, ceteris paribus, expels some firms from the formal sector and reduces aggregate profits. Alternatively, a reduction of $n$ decreases the income of shareholders, contracting the demand of all firms and making $N_{q}$ relatively higher.
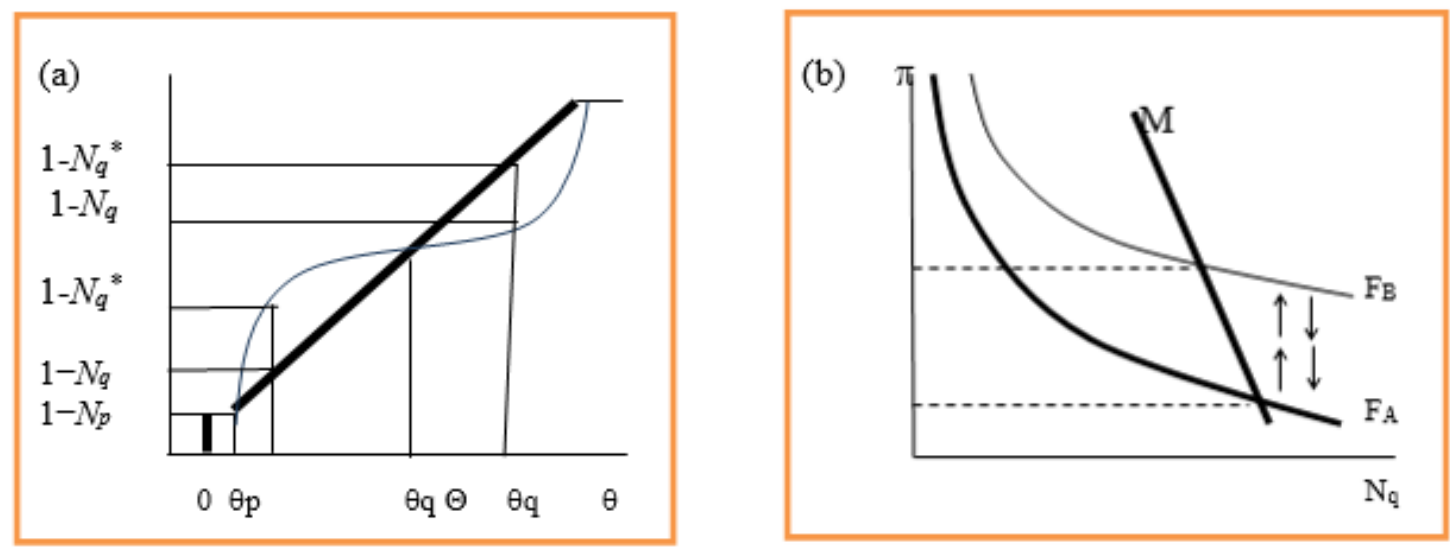

Figure 1: Mean-preserving spread of $R(\theta)$

On the other hand, the points on the $M$-curve balance the incentives a firm has to become (in)formal. For given $T$ and a an increase in $N_{q}$ should be accompanied by a proportional reduction in $\rho$ so that $\rho N_{q}$ remains unchanged. The decrease in $\rho$ comes from a fall in the number of formal sectors $q$. This implies a reduction in profits and a downward-sloped $M$-curve. As the elasticity $\varepsilon_{g}$ is assumed to be low, the $M$-curve is steeper than the $F$-curve. To analyze the consequences of redistribution of ownership on the informal sector, consider a mean-preserving spread of $R(\theta)$ as shown in Figure $1(\mathrm{a})$, where the bold line represents some share distribution, and the light line is its mean-preserving spread, $R^{*}(\theta)$. A shift from $R(\theta)$ to $R^{*}(\theta)$ is achieved by redistributing the shares from the upper class towards the middle class without modifying either the mean in $\theta \in\left[\theta_{p}, \infty\left[, \theta\right.\right.$, or the number of poor, $R\left(\theta_{p}\right)$. The effect of the poor entering the market is studied later.

(a) $\mathrm{d} \tau>0, \mathrm{~d} g<0$

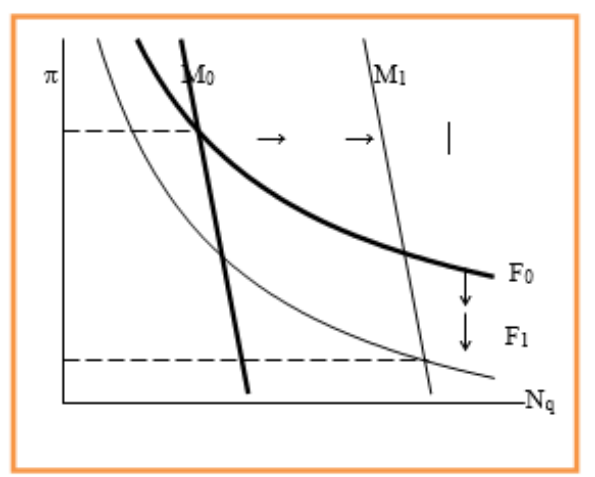

(b) $\mathrm{d} \tau>0, \mathrm{~d} g>0$

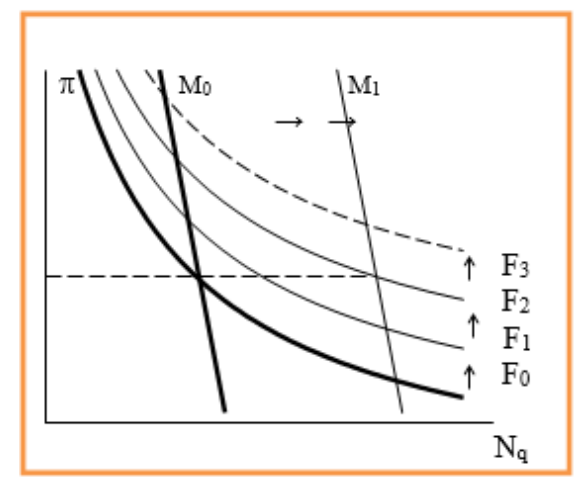

Figure 2: The public service finance by a tax increase 
Two possible cases arise depending on the initial $\theta_{\mathrm{q}}$ and, in turn, the initial degree of inequality. Recall that and $\Theta=\int_{\theta_{p}}^{\theta_{q}} \theta d R(\theta)+\int_{\theta_{q}}^{\infty} \theta d R(\theta)$, so if high values of $\theta>\theta_{q}$ are found with positive probability, the more unequal the society and the higher the odds of having $\theta_{q}<\theta$. In the opposite case, the values of $\theta$ are more concentrated around $\theta_{q}$. As a result, the shareholders are more homogenous and $\theta_{q}>\theta$ is a more likely outcome.

If $\theta_{q}<\theta$, the initial situation implies high inequality within the upper class and between it and the middle class. As shown in Figure 1 (a) after redistribution, $R^{*}\left(\theta_{p}\right)>R\left(\theta_{p}\right)$ (i.e. $1-N_{q}^{*}>1-N_{q}$ ) so the fixed break-even demand of the marginal firm $N_{q}$ falls, increasing the number of firms operating formally. As expected, redistribution raises the share of profits held by the middle class, $\Theta_{q}^{*}>\Theta_{q}$, and, in doing so, raises the profit multiplier in (4). Notably, in itial high inequality implies that after redistribution, a sizeable upper class still exists, so the entry costs of formal firms are still covered while sales from informal firms decrease. As Figure $1(b)$ shows, the $F$-curve shifts up from $F_{A}$ to $F_{B}$. Given the higher profits and lower $N_{q}$ in the new equilibrium, the size of the informal economy declines. However, the $M$-curve may shift to the left as a result of a higher $\rho$ due to the effects of a larger formal sector on tax revenues. The direction of this change reinforces the expansion of the $F$-curve and the conclusion is the same.

On the other hand, redistribution under $\theta_{q}>\Theta$ renders the opposite outcome: it ra ises $N_{q}$ and lowers $\Theta_{q}$, so the $F$-curve falls from $F_{B}$ to $F_{A}$ in Figure $1(b)$. Initially, the upper class was close to the middle class, so the natural consequence of a drop in the former makes firms use part of their revenues from the middle class to cover their costs after redistribution. As a result, profits decrease, leading to a larger informal sector.

\subsection{Tax and State Intervention}

Now consider an increase in the tax rate, $\mathrm{d} T>0$. This shock, depending on its effects on the tax base $\mathrm{q}$, can either increase or decrease tax revenues and fiscal expenditure (since $g=T q$ ). The latter response is crucial for the following analysis as it defines the direction in which $\rho$ moves and, subsequently, the movements of the $M$ - and $F$-curves.

Suppose first that $\mathrm{d} T>0$ and $\mathrm{d} g<0$, which implies that $(\mathrm{d} T / T)<-(\mathrm{d} q / q)$ and, importantly, that $\mathrm{d} \rho<0$. This situation is shown in Figure 2(a). The $M$-curve shifts to the right (from $M_{0}$ to $M_{1}$ ) as a consequence of the higher entry costs that are reinforced by a decline in the benefits of formality, $\rho$. As the reduction in $\rho$ shrinks the profit multiplier in (4), the $F$-curve contracts from $F_{0}$ to $F_{1}$. The new equilibrium, with higher $N_{q}$ and lower $n$, is characterized by a smaller number of formal sectors $(\mathrm{d} q<0)$ and lower sales both in the formal sector $\left(d S^{F}<0\right)$ and in the whole economy $(\mathrm{d} S<0)$. The effect on the relative size of the informal sector is, however, ambiguous. The labor demand for formal firms decreases in response to lower sales, but increases as the unit labor requirement $\mathrm{a}(1-\rho)$ become higher. If the first effect dominates, then the informal share of the economy increases $\left(d L^{I}=d S^{I}>0\right)$.

For this case to be feasible, q must be very responsive to the tax change. This is likely to happen when $N_{q}$ is initially small, which implies a high value for $\theta_{q}$. As seen in the previous subsection, this setup is consistent with a large middle class in conjunction with a reduced upper class, i.e., low initial inequality. Hence, the drop in sales following the reduction in the income (as $\mathrm{d} n<0$ ) appears to dominate the needs for more labor in the formal sector, implying a sharp contraction of the $F$-curve and a larger informal sector. This is the static comparative result of models with no distributional features as Rauch (1991). Note that the percentage increase in $T$ is greater than that of $\rho$. The $M$-curve shifts to the right as long as $(\mathrm{d} T / T)>-\varepsilon_{g}\left(1-\varepsilon_{g}\right)(\mathrm{d} q / q)$, which is satisfied if $(\mathrm{d} T / T)>-(\mathrm{d} q / q)$ holds.

Consider now that $\mathrm{d} T>0$ and $\mathrm{d} g>0$, which implies that $(\mathrm{d} T / T)>-(\mathrm{d} q / q)$ and $\mathrm{d} \rho>0$. 
As shown in Figure 2(b), the $M$-curve shifts to the right (from $M_{0}$ to $M_{1}$ ) again but the $F$-curve expands, delivering three possible outcomes. If the shift is from $F_{0}$ to $F_{1}$, in the new equilibrium the drop in profits translates into a smaller number of formal industries, lower overall sales, and lower formal sector sales ( $\mathrm{d} q, \mathrm{~d} S$, and $d S^{F}$ ) are all negative). However, the drop in $S^{F}$ together with the higher benefit from being formal (lower input requirement, $a(1-\rho)$ since $\mathrm{d} \rho>0$ ) leads unambiguously to a lower labor demand from formal firms and a broader operating informal sector.

The equilibrium resulting from the shift from $F_{0}$ to $F_{2}$ (where $\mathrm{d} n=0$ ) is qualitatively similar to the one just described, with the critical difference that $\mathrm{d} S=0$, so that the change in the size of the informal sector is, albeit positive, smaller. Notice that, ceteris paribus, the value of $\Theta_{q}$ implied in the curve $F_{2}$ is higher than the one associated with $F_{1}$. Hence, a larger middle class or lower inequality, by increasing the multiplier, makes the (expansionary) effects of a larger provision of public good (more fiscal resources, in general) more powerful.

This fact opens the possibility of ending up in the intersection of $M_{1}$ with an $F$-curve above $F_{2}$ (for instance, $\left.F_{3}\right)$. This equilibrium will have different properties from the previous ones as the tax increase raises both $N_{q}$ and $n$, and, notably, it may have a smaller informal sector as an outcome. For a given $\Theta_{q}$, consistent mainly with $(\mathrm{d} T / T)>-(\mathrm{d} q / q)$, this case may arise if $\rho$ is large enough, i.e. if the public good or service is justly productive. The positive relationship between $T$ and the size of the informal sector is in line with the empirical finding in Friedman et al., (2000).

\section{Hypotheses, Variable Measurements, and Data}

\subsection{Hypothesis}

The construction made in the previous section provides two empirically testable predictions regarding the effects of income concentration on the size of the informal sector in an economy. Firstly, income concentration affects informality directly, as it allocates resources between those who purchase only formal goods and those who also consume informal goods. Specifically, high inequality leads to a large informal sector. By the same token, if inequality is high or the amount of wealth concentrated in the upper class is disproportionately large, redistribution towards the middle class reduces informality. On the contrary, if inequality is relatively low, redistribution may weaken the upper class and reduce the base spending that pushes firms to formality.

Secondly, income concentration also affects the way informality responds to fiscal changes that affect either the demand or the supply side of the economy. In particular, the more unequal a society, the less powerful the fiscal policy. As the middle class expands, the marginal effects of a further fiscal intervention against informality are reinforced. This analysis suggests therefore that redistributive policies promoted by the government may trigger a virtuous circle in reducing the size of the informal sector ${ }^{6}$.

\subsection{Data and Variable Measurements}

The data, sourced from National Accounts, World Bank, International Monetary Fund, International Labor Office, International Institute for Labor Studies, and Schneider, Buehn and Montenegro (2010), and Hassan and Schneider (2016), is of annual frequency covering the period 1991-2013. The period we have chosen is particularly interesting because it refers to a context of fragile growth, characterizing many African countries. 6. The sectoral distribution of the informal sector reflects its role as a supplier of goods and services to low-
income consumers. 
The dependent variable is the size of the informal sector. This variable is comp licated to estimate for the same reason as defining it is difficult. The sector is constituted by the unofficial, all of that which is generally not observed. Thus, many approaches to providing estimates essentially try to isolate parts of incomes orvario us input demands which cannot be expla ined by the official measures of an economy's size and take these parts as estimates of the size of the informal sector. This includes macro-economic or "indirect" approach, such as monetary (cash demand) methods, physical input (electricity demand) methods, labor force discrepancy, and income and expenditure discrepancy approach. These methods are all subject to a range of problems, especially measurement error, and provide very crude estimates, which tell us nothing about the structure of the informal sector. An attempt to deal with some of these flaws is the structural covariance matrix model or Multiple-Indicators and Multiple-Causes (MIMIC) approach.

A MIMIC model is the simultaneous specification of a factor model and a structural model. This method identifies and utilizes several explanatory indicators simultaneously, which is a significant progress compared to the simpler approaches. However, this method still uses many of the same indicators and is thus subject to some of the same flaws. A different class of estimates is provided by micro-economic or "direct" approaches, such as surveys based on questionnaires and tax auditing reports. While these can be significantly biased (they often provide much lowerestimates than the "indirect" approaches), they provide much more detailed information, which can give some indication of the structure of the informal sector (Thomas, 1992; Schneider and Enste, 2002; Bajada and Schneider, 2005; Kristoffersen, 2011). Data used in our study largely comes from this method. In our empirical investigation, we also use other variables (independents variables) which are respectively: Gini index, final consumption expenditure, consumer price index, the percentage of informal employment, and taxes on income.

The last variable, "Taxes on income, profits, and capital gains," are levied on the actual or presumptive net income of individuals, on the profits of corporations and enterprises, and capital gains, whether realized or not, on land, securities, and other assets. Intra-governmental payments are eliminated in consolidation. "Informal employment" is understood to include all remunerative work - both self-employment and wage employment - that is not recognized, regulated or protected by existing legal or regulatory frameworks and non-remunerative work undertaken in an income-producing enterprise ${ }^{7}$. "Consumer price index" reflects changes in the cost to the average consumer of acquiring a basket of goods and services that may be fixed or changed at specified intervals, such as yearly ${ }^{8}$. "Final consumption expenditure" (formerly total consumption) is the sum of household final consumption expenditure (formerly private consumption) and general government final consumption expenditure (formerly general government consumption).

"Gini index" measures the extent to which the distribution of income (or, in some cases, consumption expenditure) among individuals or households within an economy deviates from a perfectly equal distribution. A Lorenz curve plots the cumulative percentages of total income received against the cumulative number of recipients, starting with the poorest individual or household. The Gini index measures the area between the Lorenz curve and a hypothetical line of absolute equality, expressed as a percentage of the maximum area under the line. Thus a Gini index of 0 represents perfect equality, while an index of 100 implies perfect inequality. For the majority of countries, data by class is not available.

The size of the informal economy in Africa varies enough from region to region, and from country to country. In the total regression, regional dummies reveal strong regional differences, which

\footnotetext{
7 This definition was adopted by the International Conference of Labor Statisticians (ICLS) during its $17^{\text {th }}$ Conference in 2003.

8 The Laspeyres formula is generally used.
} 
cannot be explained solely by economic or regional diversity. This due to the fact that behavioral differences and society (for example labor practice) are important and that the pure rational behavior approach is not sufficient for explaining the size of the informal economy. The (macro)economic indicators do not capture these differences fully. We include: (1) A data set by Botero et al. (2004) which measures different aspects of labor legislation, which here are aggregated to one index for "labor regulation intensity". (2) A set of governance indicators by Kaufmann-Kraay-Zoido-Lobatón (2002): "government effectiveness" combines perceptions of the quality of public service provision, the quality of the bureaucracy, the competence of civil servants, the independence of the civil service from political pressures, and the credibility of the government's commitment to policies into a single grouping. We update these two indicators to uniform with the period covered by the panel.

\section{Empirical Results}

In this section, we study the empirical results and implications of the theoretical model above. Table 1 presents the summary of the main statistics. It appears that the size of informal sector is too high in mean, either by Schneider and Klingmair approach (0.36), or by Macroelectric Approach (0.39), with a standard deviation of 0.12 and 0.21 respectively. High rates of informality are generally associated with low levels of GDP per capita. This correlation suggests that factors which help to lower the size of the informal economy could also contribute to an improvement in living conditions and disposable incomes in Africa economies. If total sales are determined by the income, and if income is lower (Gini index is 0.45 by means, which show the high rate of inequality in Africa), this can lower profits of shareholder and taxes revenues of the state. The percentage of tax remains high in some countries with a maximum of $79.54 \%$. In these cases, new forms of informal employment arise as a reaction to countries' tax and regulation systems, pushing some on the sidelines to try to avoid the adverse consequences of those systems. But, it is possible that the initial increases in the size of the informal economy may later be reversed when the formal sector grows faster as a result of economic growth. These primary observations must be supported and justified by strong analysis. The remains tables document the empirical and predicted relationship between informal sector size and wage independent variables.

Table 1: Summary Panel Statistics

\begin{tabular}{|l|l|l|l|l|l|}
\hline & Mean & $\begin{array}{l}\text { Standard } \\
\text { deviation }\end{array}$ & Min & Max & $\begin{array}{l}\text { Number of } \\
\text { observations }\end{array}$ \\
\hline $\begin{array}{l}\text { Size of Informal Sector } \\
\text { - Schneider and }\end{array}$ & 0.36 & 0.12 & - & - & 494 \\
$\begin{array}{l}\text { Klingmair } \\
\text { - Macroelectric Approach }\end{array}$ & 0.39 & 0.21 & - & - & - \\
\hline Gini Index & 0.45 & 0.09 & 30 & 61 & 494 \\
\hline Taxes on Income & 28.48 & 10.21 & 9.06 & 79.54 & 494 \\
\hline $\begin{array}{l}\text { Final Consumption } \\
\text { Expenditure }\end{array}$ & $54,143 \mathrm{E}+08$ & $0,960 \mathrm{E}+08$ & $10,433 \mathrm{E}+08$ & $99,454 \mathrm{E}+08$ & 494 \\
\hline ConsumerPrice Index & 109,64 & 98,90 & 1.80 & 415034,44 & 494 \\
\hline $\begin{array}{l}\text { Percentage of Informal } \\
\text { Employment }\end{array}$ & 55.7 & 7.9 & 11.5 & 90.4 & 494 \\
\hline $\begin{array}{l}\text { LaborRegulation } \\
\text { Intensity }\end{array}$ & 12.33 & 7.43 & 0 & 100 & 494 \\
\hline $\begin{array}{l}\text { Government } \\
\text { Effectiveness }\end{array}$ & 0.09 & 2.10 & -2.5 & +2.5 & 494 \\
\hline
\end{tabular}

All estimations are made estimated by a sample of Africa countries on which data are available (see table 5 in the appendix). As indicated previously, our dependent variable, size of the informal sector is measured by two methods: the currency demand approach (Schneider and Klingmair, 2003) and the Macroelectric Approach (Kaufmann and Kaliberda, 1996). These two 
methods use the percentage of official GDP. In respect to our model, we take the GDP percapita. Concerning the independent variables, we use the initial Gini index to summarize the income concentration, final consumption expenditure, consumer price index, percentage of informal employment (lower class), and taxes on income (percentage of total taxes). We control estimation with labor regulation intensity and government effectiveness.

We begin by investigating the stationary properties of the data (Table 2), as this can influence the estimation procedure we choose. Since we have only $\mathrm{I}(0)$ variables, we do not opt to use the GETs ${ }^{9}$ procedure as it is still an open debate on how to appropriately handle combinations of stationary and non-stationary variables in standard cointegration frameworks like that of Johansen. The model is also well-behaved in terms of the diagnostic tests. The residuals do not suffer from non-normality, serial correlation or heteroskedasticity. Also, the Ramsey RESET test suggests that the model is well specified.

Table 2: Stationary Panel (Unit Root) Tests

\begin{tabular}{|l|l|l|l|l|}
\hline & $\begin{array}{l}\text { Assumes Common } \\
\text { Unit Root Process }\end{array}$ & \multicolumn{2}{l|}{ Assumes Individual Unit Root Process } \\
\hline & Levin, Lin \& Chut & $\begin{array}{l}\text { Im, Pesaran } \\
\text { and Shin W- } \\
\text { stat }\end{array}$ & $\begin{array}{l}\text { ADF - } \\
\text { Fisher Chi- } \\
\text { square }\end{array}$ & $\begin{array}{l}\text { PP - Fisher } \\
\text { Chi-square }\end{array}$ \\
\hline $\begin{array}{l}\text { Size of Informal Sector } \\
\text { - Schneider and Klingmair } \\
\text { - Macroelectric Approach }\end{array}$ & -1.782 & -1.665 & $\begin{array}{l}1.545 \\
0.777 * * *\end{array}$ & $0.628^{* *}$ \\
\hline Gini Index & $-3.212^{* *}$ & -1.522 & 2.387 & 2.255 \\
\hline Taxes on Income & $-2.652^{*}$ & $-2.759 * *$ & 0.253 & $0.729 * *$ \\
\hline $\begin{array}{l}\text { Final Consumption } \\
\text { Expenditure }\end{array}$ & -0.181 & -2.444 & 11.191 & $1.500^{* * *}$ \\
\hline ConsumerPrice Index & $-2.544^{* *}$ & -19.79 & & 1.436 \\
\hline $\begin{array}{l}\text { Percentage of Informal } \\
\text { Employment }\end{array}$ & 1.073 & -27.761 & 4.867 & $10.34 * *$ \\
\hline LaborRegulation Intensity & - & -3.777 & $19.21 * * *$ & - \\
\hline Govemment Effectiveness & - & & - & - \\
\hline
\end{tabular}

$10 \%, 5 \%$, and $1 \%$ levels, respectively. Probabilities for Fisher tests are computed using an asymptotic Chi-square distribution. All other tests assume asymptotic normality.

Table 3 shows two-panel regressions findings based on 38 countries and using the two alternatives measures of the informal sector. Although the model provides a nearperfect fit, the parameters are precisely estimated. According to the estimations by fixed effects ordinary least squares, the coefficient associated with the Gini index is positive and statistically significant at $5 \%$ level, which implies that higher inequality concentration in income tends to increase the size of the informal sector, as predicted by the model (Chong and Gradstein, 2007). A one percentage point increase in the Gini index rate leads to roughly more than 0.06 percentage point rise in informal sector. Moreover, the coefficient of the interaction term is also positive, which implies that higher inequality reduces the effect of more fiscal resources on informality (which is negative). This finding is also supportive of the predictions of the theory. Nonetheless, these results are to be handled with care as they are only significant at a $10 \%$. Perhaps a higher lower class implies a lower degree of formality. When job-creation in the formal sector slows

\footnotetext{
9 The GETs (general-to-specific) approach helps to eliminate statistically irrelevant variables thus reducing this "general" model to a more parsimonious, congruent one, allowing for more efficient estimation and inference.
} 
down, families in need of income send members into the informal sector. The high inequality ${ }^{10}$ observed in the African case is likely to be driving this finding.

In particular, the results show a negative impact of the tax on informality ${ }^{11}$. Higher tax rates are not associated with a small informal sector (Lewis (2004; Farrell, 2004). It is possible that high tax rates increase tax revenues that would enable the government to finance a stronger legal environment and, consequentially, to reduce informality. A tax rate reduction may initially appearto reduce the tax revenue base, but it must be undertaken in an effort to include informal enterprises and, thereby, greatly expand the overall tax base. More progressive taxes need to be introduced in order to achieve vertical equity. This would improve the image of the tax system which would help lure informal workers into the formal sector.

Table 3: Static Panel Data

\begin{tabular}{|c|c|c|c|c|}
\hline & \multicolumn{2}{|r|}{ PanelOLS } & \multicolumn{2}{|r|}{ PanelIV } \\
\hline & {$[1]$} & {$[2]$} & [3] & [4] \\
\hline Constant & $\begin{array}{r}-0.029 \\
(0.02)\end{array}$ & $\begin{array}{r}-0.038 * \\
(0.02)\end{array}$ & $\begin{array}{r}-0.029 \\
(0.02)\end{array}$ & $\begin{array}{r}-0.031 \\
(0.02)\end{array}$ \\
\hline Gini Index & $\begin{array}{r}0.088 * * \\
(0.45)\end{array}$ & $\begin{array}{r}0.064^{*} \\
(0.43)\end{array}$ & $\begin{array}{r}0.076 * * \\
(0.34)\end{array}$ & $\begin{array}{r}0.098^{*} \\
(0.44)\end{array}$ \\
\hline Taxes on Income & $\begin{array}{r}-0.243^{* *} \\
(0.10)\end{array}$ & $\begin{array}{r}-0.217 * * \\
(0.10)\end{array}$ & $\begin{array}{r}0.243 * * \\
(0.10)\end{array}$ & $\begin{array}{r}-0.175^{*} \\
(0.10)\end{array}$ \\
\hline $\begin{array}{l}\text { Final Consumption } \\
\text { Expenditure }\end{array}$ & $\begin{array}{r}-0.009 \\
(0.09)\end{array}$ & $\begin{array}{r}-0.034 \\
(0.08) \\
\end{array}$ & $\begin{array}{r}-0.009 \\
(0.09) \\
\end{array}$ & $\begin{array}{l}0.000 \\
(0.09) \\
\end{array}$ \\
\hline ConsumerPrice Index & $\begin{array}{r}0.587 * * \\
(0.13)\end{array}$ & $\begin{array}{r}1.313 * * \\
(0.42)\end{array}$ & $\begin{array}{r}0.587 * * \\
(0.13)\end{array}$ & $\begin{array}{r}1.973 * * \\
(0.56)\end{array}$ \\
\hline $\begin{array}{l}\text { Percentage of Informal } \\
\text { Employment }\end{array}$ & $\begin{array}{c}-0.271^{*} \\
(0.15 \\
)\end{array}$ & $\begin{array}{r}-0.297 * \\
(0.15)\end{array}$ & $\begin{array}{r}-0.271 * \\
(0.15)\end{array}$ & $\begin{array}{r}-0.199 \\
(0.18)\end{array}$ \\
\hline $\begin{array}{l}\text { Gini Index* Final } \\
\text { Consumption }\end{array}$ & $\begin{array}{r}0.350 * * \\
(0.16)\end{array}$ & $\begin{array}{l}0.135 \\
(0.19)\end{array}$ & $\begin{array}{r}0.350 * * \\
(0.16)\end{array}$ & $\begin{array}{l}-0.171 \\
(0.25)\end{array}$ \\
\hline Labor Regulation Intensity & $\begin{array}{r}0.344^{*} \\
(0.07)\end{array}$ & $\begin{array}{l}0.224 \\
(0.04)\end{array}$ & $\begin{array}{l}0.109 \\
(0.02)\end{array}$ & $\begin{array}{l}0.132 \\
(0.00)\end{array}$ \\
\hline Govemment Effectiveness & $\begin{array}{l}0.091 \\
(0.01) \\
\end{array}$ & $\begin{array}{l}0.089 \\
(0.01) \\
\end{array}$ & $\begin{array}{l}0.073 \\
(0.00) \\
\end{array}$ & $\begin{array}{l}0.079 \\
(0.01) \\
\end{array}$ \\
\hline Nobs. & 488 & 488 & 480 & 480 \\
\hline $\mathrm{R}^{* * 2}$ & 0.1426 & 0.1541 & 0.1671 & 0.1780 \\
\hline
\end{tabular}

Notes: Regressions are performed with fixed effects. $\left(^{*}\right)$ statistically significant at $10 \%$; (**) statistically significant at $5 \%$; $(* * *)$ statistically significant at $1 \%$. Standard errors are in parenthesis.

Governments can significantly influence levels of income inequality through taxes and expenditures. Indeed, this is why it is imperative to look for changes in government budgets particularly taxes and transfers -to help drive the distribution of disposable income towards greater equality. Progressive tax and pro-poor expenditure will reduce poverty.

Finally, the coefficient of the final consumption yields an unexpected negative sign, although it is weakly statistically significant. Perhaps when aggregate demand is high, and businesses are more likely to flourish, and there is always a wage-employment safety net that lowers the risks of becoming a formal entrepreneur, therefore lowers the size of the formal sector.

${ }^{10}$ The dual nature of inequality, with upper-class wage carrying an earnings premium that may compensate for the benefits of informal wage work and middle-class jobs could be largely penalized. One may also claim that formal-salaried workers have better unobservable skills compared to their informal counterparts because results are obtained by controlling for only observable characteristics.

${ }^{11}$ At the firm level, a tax increase has a negative effect on the profits on the marginal firm. 
The results of the regressions show that labor regulations significantly influence the size of the informal sector; in all regressions, the influence is significant at the $5 \%$ level with the expected (positive) sign: i.e., higher inflexibility in labor regulations is associated with a larger informal economy. A strongly significant influence is also shown about the index for government effectiveness; in other words, more efficient government reduces the relative size of the informal sector. This may occur through a better rule of law, thus increasing the advantages of working in the formal sector, and a higher probability of detection for firms working in the informal one.

Institutional reform is likely to exacerbate inequality in countries where there is a large informal sector. It seems likely that changes in labor market institutions have contributed significantly to rises in wage inequality and overall inequality, especially in middle-income. "As employment became more informal, wage shares declined and the difference between skilled and unskilled wages increased in many countries" (Cornia and Court, 2001).

In columns 3 and 4 of Table 3, we tackle the potential endogeneity problem between income concentration and the size of the informal sector by using an IV technique and the same instruments. Overall, we obtain virtually the same results as in the pooled fixed effects case that is, a positive coefficient in the Gini index term, and a negative coefficient in the interactive term.

Table 4: Dynamic Panel Data Approach

\begin{tabular}{|c|c|c|}
\hline & [1] & {$[2]$} \\
\hline Constant & $0.779 * *(0.09)$ & $-0.182 *(0.11)$ \\
\hline Lagged Informal Size & $0.532 *(0.25)$ & $-0.157 *(0.06)$ \\
\hline Gini Index & $0.059 * *(0.01)$ & $0.083 *(0.05)$ \\
\hline Taxes on Income & $-0.896 * *(0.15)$ & $-0.253 * *(0.06)$ \\
\hline Final Consumption Expenditure & $-0.123 * *(0.06)$ & $-0.236 * *(0.10)$ \\
\hline ConsumerPrice Index & $0.094 * *(0.04)$ & $-1.265 *(0.75)$ \\
\hline $\begin{array}{l}\text { Percentage of Informal } \\
\text { Employment }\end{array}$ & $0.172 * *(0.09)$ & $-0.109(0.13)$ \\
\hline Gini Index* Final Consumption & $0.080 * *(0.02)$ & $0.337 * *(0.06)$ \\
\hline Labor Regulation Intensity & $0.241^{*}(0.05)$ & $0.204(0.03)$ \\
\hline Govemment Effectiveness & $0.071(0.00)$ & $0.088(0.01)$ \\
\hline No. Observations & 493 & 493 \\
\hline $\mathrm{R}^{* * 2}$ & 0.373 & 0.371 \\
\hline $\begin{array}{l}\text { Specification Tests (p-values) } \\
\text { - Sargan Test } \\
\text { - 2nd-Order Correlation }\end{array}$ & $\begin{array}{l}(0.893) \\
(0.301)\end{array}$ & $\begin{array}{l}(0.872) \\
(0.326)\end{array}$ \\
\hline
\end{tabular}

Notes: $\left(^{*}\right)$ statistically significant at $10 \% ;(* *)$ statistically significant at $5 \%$; (***) statistically significant at $1 \%$. Standard errors are in parenthesis.

We also applied a GMM-IV dynamic panel data methodology (Table 4), that allows us to take into account unobserved country and time specific effects, control for potential endogeneity of the explanatory variables. Using this method, we estimate a regression equation in differences and a regression equation in levels simultaneously, with each equation using its own specific set of instrumental variables. With this method, the precedent result is confirmed.

\section{Conclusion}

In this paper we have studied the relationship between income concentration and size of the informal sector, using annual panel data in macro-level. We propose a simple theoretical model in which firms decide simultaneously the quantity of output to produce and the sector in which to operate, on the production side. Each sector embodies a different technology. Formal firms produce under increasing returns to scale as they can use productive public services in exchange of tax payment. Informal firms, on the other hand, neither pay taxes nor access to public services benefits. It follows that it is easier 
to comply with the prevailing regulations if the demand firms face for a given fiscal burden (tax rate) is large enough. In otherwords, the larger the demand that a firm has to meet, the higher the benefits from formality. This fact establishes a link with the demand side on the model which is entirely determined by the income distribution.

Overall, the empirical findings are consistent with the basic predictions of the model, in particular regarding the hypothesis that: (1) income concentration affects informality directly, as it allocates resources between those who purchase only formal goods and those who also consume informal goods. Specifically, high inequality leads to a large informal sector. (2) Income concentration also affects the way informality responds to fiscal changes that affect either the demand or the supply side of the economy. In particular, the more unequal a society, the less powerful the fiscal policy. We test our theory using fundamental variables particularly those concerning the size of the informal sector and income concentration, and other control variables to confirm our model. We also use a two range of econometric techniques for a panel sample of countries, particularly ordinary least squares and instrumental variables, as well as pooled fixed effects and dynamic panel data models.

The informal sector supplies both income and goods to the poor. Policies and programs directed at the informal sector, therefore, have significant poverty-reducing potential. The occupational configuration within the informal sector indirectly corroborates its role as a self-help safety net for low-income families, while its distribution across activities demonstrates its role as a supplier of goods and services for low-income consumers.

\section{References}

- Bajada, C. and Schneider, F. (2005), An International Comparison of Underground Economic Activity, in C. Bajada and F. Schneider (eds.), Size, Causes and Consequences of the Underground Economy, An International Perspective, pp. 73-106, Ashgate.

- Bargain, O. and Kwenda, P. (2011), Earnings Structures, Informal Employment, and Self Employment: New Evidence from Brazil, Mexico, and South Africa, Review of Income and Wealth, No 57, pp. S100-S122. $\underline{\text { Crossref }}$

- Barro, R. J. and Sala-i-Martin, X. (1992), Public Finance in Models of Economic Growth, Review of Economic Studies, vol. 59, No 4, pp. 645-661. Crossref

- Bernanke, B. S. and Gürkaynak, R. S. (2002), Is Growth Exogenous? Taking Mankiw Romer and Weil seriously, in B.S. Bernanke and K.S. Rogoff. (eds.), NBER Macroeconomics Annual 2001, Cambridge, MA: MIT Press.

- Botero, J., Djankov, S., La Porta, R., Lopez-de-Silanes, F., and Shleifer, A. (2004), The Regulation of Labour, World Bank.

- Charmes, J. (2000), The Contribution of Informal Sector to GDP in Developing Countries: Assessment, Estimates, Methods, Orientations for the Future, OECD-EUROSTAT-State Statistical Committee of the Russian Federation, Non-Observed Economy Workshop, Sochi (Russia), October 16-20.

- Chong, A. and Gradstein, M. (2007), Inequality and Informality, Journal of Public Economics, vol. 91, No 1, pp. 159-179. Crossref

- Cornia, G. A. and Court, J. (2001), Inequality, Growth and Poverty in the Era of Liberalization and Globalization, United Nations University/WIDER, Helsinki.

- Dereck, B. and Lugo, A. M. (2011), The Informal Economy in Developing Countries: An Introduction, Review of Income and Wealth, Series 57, Special Issue, May 2011, pp. S1-S7.

- Farrell, D. (2004). The Hidden Dangers of the Informal Economy, McKinsey Quarterly, pp. 26-37.

- Friedman, E., Johnson, S., Kaufmann, D. and Zoido-Lobaton, P. (2000), Dodging the Grabbing Hand: The Determinants of Unofficial Activity in 69 Countries, Journal of Public Economics, vol. 76, No 3, pp. 459-493. Crossref

- Gollin, D. (2002), Getting Income Shares right, Journal of Political Economy, No 110, pp. 458-74. Crossref 
- Gray, K., Howard, F. and Howard, F. (2006), Motivations of Moroccans to be Entrepreneurs, Journal of Developmental Entrepreneurship, Vol. 11, No 4, pp. 279-318. Crossref

- Grimm, M., Krüger, J. and Lay, J. (2011), Barriers to Entry and Returns to Capital in Informal Activities: Evidence from Sub-Saharan Africa, Review of Income and Wealth, No 57, pp. S27S53. Crossref

- Hassan, M. and Schneider, F. (2016), Size and Development of the Shadow Economies of 157 Countries Worldwide: Updated and New Measures from 1999 to 2013, IZA Discussion Paper No. 10281.

- Johnson, S., Kaufmann, D. and Shleifer, A. (1997), The Unofficial Economy in Transition, Brooking Papers on Economic Activity, No 2, pp. 159-239.

- Kaufmann, D. and Kaliberda, A. (1996), Integrating the Unofficial Economy into the Dynamics of the Post-Socialist Economies: A Framework of Analysis and Evidence, World Bank Policy Research Working Paper, 1691, Washington, D. C., United States: World Bank.

- Kaufmann, D., Kraay, A., and Zoido-Lobatón, P. (2002), Governance Matters II, Updated Indicators for 2000/01, The World Bank, Policy Research Working Paper, 2772.

- Kravis, Irving B. (1962), The Structure of Income: Some Quantitative Essays. Philadelphia: University of Philadelphia Press.

- Kristoffersen, S. (2011), Taxation and Informal Sector Growth in Developing Countries, Master Thesis, Department of Economics University of Oslo.

- Levenson, A. R. and Maloney, W. R. (1998), The Informal Sector, Firm Dynamics and Institutional Participation, World Bank Policy Reserach Working Paper, 1988.

- Lewis, W. W. (2004), The Power of Productivity: Wealth, Poverty, and the Threat to Global Stability, University of Chicago Press. Crossref

- Loayza, N. V. (1996), The Economics of the Informal Sector: A Simple Model and some Empirical Evidence from Latin America, Carnegie-Rochester Conference Series on Public Policy, No 45, pp. 129-162. rossref

- Rauch, J. E. (1993). Economic Development, Urban Underemployment and Income Inequality, Canadian Journal of Economics, vol. 26, No 4, pp. 901-918. Crossref

- Roberts, B. (1994), Informal Economy and Family Strategies, International Journal of Urban and Regional Research, vol. 16, No 1, pp. 6-23. Crossref

- Schneider, F. (2011), Handbook on the Shadow Economy, Elgar Original Reference Series, Edward Elgar Pub. Crossref

- Schneider, F. (2014), The Shadow Economy and Shadow Economy Labor Force, CESifo Working Paper Series No. 4829, 29 p. Crossref

- Schneider, F. and Buehn, A. (2009), Shadow Economies and Corruption All Over the World: Revised Estimates for 120 Countries, Economics: The Open-Access, Open-Assessment EJournal, No 1, 2007-9 (Version 2).

- Schneider, F., Buehn, A. and Montenegro, C. E. (2010), Shadow Economies All over the World, New Estimates for 162 Countries from 1999 to 2007 (Revised Version), Policy Research Working Paper, 5356.

- Schneider, F. and Enste, D. H. (2002), The Shadow Economy, An International Survey, Cambridge University Press.

- Schneider, F. and Klingmair, R. (2003), Shadow Economies around the World: What do we know?, Linz-Auhof, Austria: Johannes Kepler University, Manuscript.

- Thomas, J. J. (1992), Informal Economic Activity, LSE Handbooks in Economics, Harvester Wheatsheaf.

- Van der Berg, S., Burger, R., Burger, R., Louw, M. and Yu, D. (2005), Trends in Poverty and Inequality since the Political Transition, Bureau for Economic Research, Dept. of Economics. The University of Stellenbosch, 1/2005. 
Income Concentration, Market Size and Informal Sector in Africa Tchakounté Njoda Mathurin, Hamit Halou Chalout

\section{Appendix}

Table 5: Full List of Countries included in Estimations

\begin{tabular}{|l|l|}
\hline 1. Algeria & 2. Madagascar \\
\hline 3. Benin & 4. Malawi \\
\hline 5. Botswana & 6. Mali \\
\hline 7. Burkina Faso & 8. Mauritania \\
\hline 9. Burundi & 10. Morocco \\
\hline 11. Cameroon & 12. Mozambique \\
\hline 13. Cape Verde & 14. Namibia \\
\hline 15. Central African Republic & 16. Niger \\
\hline 17. Cote d'Ivoire & 18. Nigeria \\
\hline 19. Egypt, Arab Rep. & 20. Rwanda \\
\hline 21. Equatorial Guinea & 22. Senegal \\
\hline 23. Ethiopia & 24. Sierra Leone \\
\hline 25. Gambia, The & 26. South Africa \\
\hline 27. Ghana & 28. Swaziland \\
\hline 29. Guinea & 30. Tanzania \\
\hline 31. Guinea-Bissau & 32. Tunisia \\
\hline 33. Kenya & 34. Uganda \\
\hline 35. Lesotho & 36. Zambia \\
\hline 37. Liberia & 38. Zimbabwe \\
\hline
\end{tabular}

Source: Schneider and Buehn (2009); Schneider, Buehn and Montenegro (2010). 